\title{
PENGARUH PENDIDIKAN MADRASAH DINIYAH TERHADAP PENGETAHUAN AGAMA BAGI SISWA SEKOLAH UMUM
}

\author{
Agus Khobir Permana \\ Email: www.akhop6161@gmail.com \\ Universitas Islam Al-Ihya Kuningan
}

\begin{abstract}
ABSTRAK
Pengembangan Sumber Daya Manusia merupakan faktor kunci untuk mencapai kemajuan negara dan bangsa. Menciptakan sumber daya manusia yang berkualitas tidak hanya dari segi kecerdasan intelektual, tetapi yang lebih penting adalah kecerdasan beragama. Agama mengajarkan bahwa ada kerusakan di bumi karena ulah manusia. Tercapainya kemakmuran dan kedamaian bagi seluruh umat manusia akan tercapai dan dirasakan karena adanya keseimbangan kecerdasan intelektual dan agama, sehingga diharapkan kehidupan yang damai dan terhindar dari kerusakan di muka bumi. Pemerintah mengantisipasi terwujudnya keseimbangan kecerdasan intelektual dan agama melalui pembentukan program Madrasah Diniyah Takmiliyah untuk siswa sekolah umum. Kebijakan ini diambil karena minimnya materi agama untuk siswa sekolah umum dalam kurikulum nasional. Otonomi daerah memungkinkan Kepala Daerah menetapkan Peraturan Daerah (Perda) terkait penguatan pendidikan agama yang dibutuhkan daerah dalam rangka mewujudkan kesejahteraan masyarakat.
\end{abstract}

\begin{abstract}
Human Resource Development is a key factor in achieving the progress of the state and nation. Creating quality human resources is not only in terms of intellectual intelligence, but more importantly religious intelligence. Religion teaches that there is damage on earth due to human activity. The attainment of prosperity and peace for all mankind will be achieved and felt because of the balance of intellectual and religious intelligence, so it is hoped that a peaceful life will be protected from damage on earth. The government anticipates the realization of a balance between intellectual and religious intelligence through the establishment of the Madrasah Diniyah Takmiliyah program for public school students. This policy was taken because of the lack of religious material for public school students in the national curriculum. Regional autonomy allows regional heads to stipulate regional regulations (Perda) related to strengthening religious education needed by regions in order to realize community welfare.
\end{abstract}

\section{PENGANTAR}

Visi Pemerintah Kabupaten Kuningan "Kuningan MAJU (Makmur, Agamis, Pinunjul) Berbasis Desa". Visi ini secara umum sudah menampakkan hasilnya dengan adanya kemajuankemajuan yang di raih Pemerintah Kabupaten Kuningan, namun dalam kenyataan tidak dapat kita pungkiri bahwa masih kita temukan adanya penyimpangan perilaku siswa. Siswa yang 
terlibat dalam tawuran, kenakalan remaja, pergaulan bebas yang melanggar norma agama bahkan ada yang terlibat obat-obat terlarang. Karakter pelajar yang buruk seperti itu menjadi tanggungjawab orang tua, pemerintah dan masyarakat. Salah satu strategi untuk menanggulanginya adalah melalui penguatan pendidikan agama. Agama diharapkan menjadi benteng utama para pelajar untuk menjaga diri mereka masing-masing agar tidak terjebak pada perilaku yang menyimpang.

Program Madrasah Diniyah bagi siswa sekolah umum dapat diterapkan guna memperkuat pengetahuan agama. Selama ini siswa sekolah umum sangat minim memperoleh materi agama. Kurikulum Nasional hanya mengalokasikan 2 (dua) jam pelajaran agama per minggu, itupun penyajiannya banyak pada teori belaka.

Melalui tulisan ini ingin di sampaikan bagaimana program Madrasah Diniyah bagi siswa sekolah umum akan dapat membantu memperkuat pengetahuan agama peserta didik. Tulisan ini juga mengungkapkan bahwa Pemerintah Kabupaten Kuningan telah mengimplementasikan program Madrasah Diniyah untuk siswa sekolah umum melalui beberapa masjid, musholla, pondok pesantren yang ada Madrasah Diniyahnya di Kabupaten Kuningan. Terakhir melalui tulisan ini, ingin diungkapkan bagaimana secara teknis program Madrasah Diniyah ini dapat dilaksanakan bagi siswa sekolah umum, sehingga diharapkan akan terbentuk karakter akhlak mulia pada siswa sekolah umum untuk mewujudkan sumber daya manusia Indonesia yang berkualitas.

\section{PEMBAHASAN}

Pemerintah Kabupaten Kuningan dalam melaksanakan pembangunan sumber daya manusia yang berkualitas telah membangun gedung-gedung sekolah yang cukup representatif dan melengkapinya dengan sarana prasarana yang baik. Secara fisik bangunan gedung sekolahsekolah sudah cukup bagus dan mencukupi daya tampung siswa Kabupaten Kuningan. Di sisi lain, Pemerintah Kabupaten Kuningan mengharapkan agar Kabupaten Kuningan menjadi Kabupaten yang religius/agamis seperti tertuang pada visinya. Beberapa program rutin telah dilaksanakan untuk mendukung terwujudnya kabupaten agamis. Sementara itu masih diketemukan adanya perilaku yang menyimpang dari sebagian siswa yang melanggar normanorma dan aturan-aturan agama. Derasnya pengaruh negatif/godaan teknologi informatika yang disalah gunakan telah menjerumuskan siswa ke hal-hal negatif.

Selain itu ada beberapa permasalahan yang penting untuk di waspadai: (1) Adanya aliran-aliran sesat dimasyarakat yang dapat mengancam para pelajar Kabupaten Kuningan ikut-ikutan aliran 
sesat tersebut, disebabkan mereka belum mampu membaca dan memahami isi kandungan AlQur'an dengan baik; (2) Pengaruh lingkungan yang tidak kondusif menyebabkan perilaku menyimpang pada para pelajar; (3) Kurangnya pengetahuan agama islam bagi siswa pendidikan formal atau umum baik di tingkat dasar dan menengah.

Penulis menganalisa bahwa mata pelajaran agama di sekolah umum yang hanya 2 (dua) jam per minggu tidaklah cukup untuk memenuhi kebutuhan siswa akan materi agama. Jumlah 2 jam pelajaran itu pun lebih banyak materi teori. Sementara ilmu agama tidak hanya sekedar teori belaka, tapi yang lebih penting adalah implementasi dari kaidah-kaidah agama. Siswa butuh memahami konsep-konsep agama, tetapi yang lebih penting adalah memperaktekkan ajaran agama supaya tumbuh karakter yang sehat dan berakhlak mulia. Keberhasilan pondokpondok pesantren dalam membentuk karakter yang sehat dan berakhlak mulia pada para santrinya adalah karena muatan materi agamanya cukup memadai dan di peraktekkan dalam kehidupan santri sehari-hari.

Berangkat dari pemikiran pentingnya tambahan materi agama dan di peraktekkan dalam kehidupan sehari-hari maka Pemerintah melalui kerjasama dengan Kementerian Agama telah membentuk program Madrasah Diniyah Takmiiyah bagi siswa sekolah umum di Madrasahmadrasah Diniyah yang ada di Kabupaten Kuningan, salah satunya yang menjadi obyek penelitian penulis adalah Madrasah Diniyah Takmiliyah Awaliyah (MDTA) Al-Karomah di pondok pesantren Al-Karomah Desa Sukaharja Kecamatan Cibingbin Kabupaten Kuningan. Kementerian Agama melalui Dirjen Pendis telah mengeluarkan kebijakan berkaitan dengan Kurikulum yaitu : (1) Kurikulum sesuai karakteristik MDT dan semangat PP No. 19 Tahun 2005 Tentang Standar Nasional Pendidikan, maka model pengembangan kurikulum dan silabusnya bersifat desentralistik. Pengembangan kurikulum harus mengacu pada Standar Isi dan Standar; (2) Kompetensi Lulusan yang sudah ditetapkan oleh Dirjen Pendis Kemenag RI; (3) Struktur kurikulum MDT paling sedikit meliputi mata pelajaran; (4) Alqur'an, Hadits, Aqidah, Akhlaq, Fiqih, SKI dan Bahasa Arab; (4) Pemerintah berperan mengarahkan dan memfasilitasi terhadap upaya pengembangan kurikulum yang dilakukan oleh guru, komite, orang tua/wali santri serta para stakeholder lainnya; (5) Satuan ajar dan buku ajar dapat dikembangkan oleh satuan pendidikan dengan mempertimbangkan kompetensidan muatan lokal masing-masing; (6) Pemerintah menjamin kemandirian kurikulum MDT yang bervariasi sesuai orientasi dan misi dakwah pengelola dan keragaman sumber belajarnya. Ketentuan Alokasi Waktu: (1) MDTA Kelas I adalah 30 menit; (2) MDTA Kelas II s/d IV adalah 40 menit; (3) MDTW Kelas I s/d II adalah 45 menit; (4) MDTU Kleas I s/d II adalah 45 menit. 
Adapun program pengembangan diri dan pembiasaan akhlaqul karimah diberikan melalui kegiatan-kegiatan yang mengakomodasi minat, bakat dan potensi santri serta, penciptaan lingkungan religius di Madrasah Diniyah Takmiliyah. Program ini dijalankan dengan menyesuaikan kondisi lingkungan MDT di luar pembelajaran kelas.

Pola Pembelajaran di Pesantren: Bandungan dan Sorogan.

Bandungan atau wetonan berarti "memperhatikan secara seksama atau menyimak". Dalam sistem pendidikan modern bandungan disebut pula dengan sistem kolektif (collection learning atau together learning). Sistem bandungan adalah sistem transfer keilmuan atau proses belajar mengajar, dimana sekelompok santri mendengarkan seorang guru yang membaca, menerjemahkan dan menerangkan buku-buku Islam dalam bahasa Arab. Kelompok kelas dari sistem bandungan ini disebut halaqah yang artinya sekelompok santri yang belajar di bawah bimbingan seorang guru.

Sorogan adalah sistem belajar secara individual, atau seorang santri nyorog (menghadap guru sendiri-sendiri) untuk dibacakan (diajarkan) oleh gurunya beberapa bagian dari materi yang dipelajarinya, kemudian sang santri menirukannya berulang kali. Dengan sistem sorogan, setiap santri mendapat kesempatan untuk belajar secara langsung dari gurunya.

Kegiatan ekstrakurikuler merupakan kegiatan di luar mata pelajaran tetapi merupakan bagian integral dari kurikulum Madrasah Diniyah Takmiliyah. Pemilihan kegiatan ekstrakurikuler disesuaikan dengan kondisi dan kemampuan Madrasah tersebut. Tujuan khusus kegiatan ektrakurikuler adalah untuk menunjang pendidikan santri dalam mengembangkan bakat, minat kreativitas, komptensi dan kebiasaan dalam kehidupan, kemampuan kehidupan beragama, kemampuan sosial, kemampuan belajar, wawasan, kemampuan memecahkan masalah dan kemandirian. Ekstrakurikuler yang bisa diterapkan di Madrasah Diniyah Takmiliyah, antara lain:(1) Seni Tilawah/Qiro'ah; (2) Pembacaan Tahlil, Barzanji/Diba'an, Istighotsah; (3) Mudadlarah/Khitabah / Latihan Ceramah; (4) Forum Debat; (5) Imla'/Dikte/Menulis Arab (6) Khath/Seni Kaligrafi; (7) Praktik Perawatan Jenazah (Tajhizul Mayit); (8) Pembinaan dan Pengembangan Kesenian Islami; (9) Olahraga dan Beladiri; (10) Pramuka Santri. Model Kegiatan Pembiasaan Akhlaq Karimah, dapat diterapkan menggunakan strategi sebagai berikut: (1) Penggunaan pendekatan system; (2) Penciptaan komitmen bersama; (3) Pengelolahan dengan program yang jelas; (4) Perbaikan berkesinambungan. Beberapa kegiatan pembiasaan yang bisa dikembangkan antara lain: Pembiasaan Shalat Berjama'ah, Sholat Sunnah, Puasa Sunnah, Baca Qur'an dan do'a sebelum dan sesudah pelajaran madrasah, Tahlil dan Barzanji, Penegakkan kedisiplinan, Cium tangan sebagai penghormatan kepada guru, 
Latihan hidup prihatin dan kesederhanaan, Menjalani hidup penuh kemandirian, Pembiasaan Dzikir dan Wirid, Berpakaian Sopan dan Islami.

Secara teknis program Madrasah Diniyah Takmiliyah ini dapat dilaksanakan bagi siswa sekolah umum, sehingga diharapkan akan terbentuk karakter akhlak mulia pada siswa sekolah umum untuk mewujudkan sumber daya manusia Indonesia yang berkualitas.

Proses pembelajaran Madrasah Diniyah Takmiliyah yang di laksanakan di Madin-Madin waktunya fleksibel. Jika siswa belajar di sekolah umum pagi hari maka waktu pembelajran di masjid dapat dilakukan sore lepas sholat Ashar atau malam selepas sholat Maghrib. Sebaliknya jika siswa sekolah umum belajar di sekolah pada sore hari maka mereka dapat belajar Madrasah Diniyah Takmiliyah pada pagi hari, setelah sholat subuh atau setelah sholat dhuha. Kesepakatan di lakukan antara siswa dengan ustad /gurunya Program Madrasah Diniyah Takmiliyah ini dapat juga diselenggarakan di sekolah-sekolah dengan menyesuaikan kondisi sekolah masing-masing. Kepala sekolah melalui Komite Sekolah dan orang tua murid dapat bermusyawarah secara terbuka dan transparan untuk penyelenggaraannya.

\section{KESIMPULAN}

Program pendidikan Madrasah Diniyah Takmiliyah merupakan solusi terhadap kurangnya pemahaman materi agama yang dimiliki oleh siswa sekolah umum. Model pembelajaran yang sederhana di Madrasah-Madrasah Diniyah atau di Pesantren-pesantren seusai pelajaran umum kurikulum nasional diberikan pada siswa. Program Madrasah Diniyah Takmiliyah ini diharapkan mampu mengurangi perilaku menyimpang siswa sekolah umum. Pengetahuan agama yang memadai akan menjadi ketahanan jati diri siswa sekolah umum untuk menghadapi berbagai tantangan dan ancaman kehidupan modern yang serba instan dan banyaknya pengaruh negatif pada kehidupan para remaja.

\section{REFERENSI}

Direktorat Pendidikan Diniyah Dan Pondok Pesantren Direktorat Pendidikan Islam Kementerian Agama RI.2013. Pedoman Standar Pelayanan Minimal Madrasah Diniyah Takmiliyah.

Direktorat Pendidikan Diniyah Dan Pondok Pesantren Direktorat Pendidikan Islam Kementerian Agama RI.2015. Pengembangan Kurikulum Madrasah Diniyah Takmiliyah.

Direktorat Pendidikan Diniyah Dan Pondok Pesantren Direktorat Pendidikan Islam Kementerian Agama RI.2015. Pengembangan Model Pembelajaran Madrasah Diniyah Takmiliyah.

Direktorat Pendidikan Diniyah Dan Pondok Pesantren Direktorat Pendidikan Islam Kementerian Agama RI.2015. Panduan Penyelenggaraan Madrasah Diniyah Takmiliyah. 
Direktorat Pendidikan Diniyah Dan Pondok Pesantren Direktorat Pendidikan Islam Kementerian AgamaRI.2015. Standar Kelulusan dan Standar isi Mapel PAI dan Bahasa Arab Madrasah Diniyah Takmiliyah. 